\title{
EFFECT OF VA MYCORRHIZAE INOCULATION ON VEGETATIVE GROWTH IN PERENNIAL SOYBEAN.
}

\author{
Bhosale R. S. and Kanade A. M. \\ Department of Botany, ACSC, Narayangaon, Savitribai Phule Pune University, Pune \\ Email: dr.ashokkanade@gmail.com
}

\begin{abstract}
:
Perennial Soybean well known as Neonotonia wightii (Wight \& Arn.) J.A. Lackey of Fabaceae grows widely in Asian sub-continent. classified by its habit wit stem trailing and climbing with strong taproot, it has woody base and is climbing up to $10 \mathrm{~m}$. Pod are brown, linear-oblong, straight sometimes slightly with curved apex, grooved and septate between the seeds. Seeds are oblong and laterally compressed, olive-green to light reddish-brown in colour. Present experiment was carried out to study effect of VAM and Phosphorous on vegetative growth parameters like height, Number of branches, and leaves per branches. Results reflected positive curve in growth parameters of Perennial soybean.
\end{abstract}

Keywords: Perennial Soy, Neonotonia wightii, VAM.

\section{INTRODUCTION:}

Perennial soybean, Neonotonia wightii (Wight \& Arn.) J.A. Lackey is climbing and twining herbaceous legume with deep strong taproot. Though it is invasive species, it has importance as soil conditioner and weed controller. In its native habitat it is valued as forage crop for cattle, goats, sheep and other livestock. Being invasive it might be looked down but considering its nutritional value as fodder and biocontrol properties research is being carried out to improve its role in agriculture.

VAM means vesicular arbuscular mycorrhizal fungi. They improve phosphate absorption of plants which promotes growth and development. VAM grows in close association with the roots and play an important role in transfer of soil nutrients to the plant. In exchange, the plant supplies the fungus with sugars. Mycorrhizal fungi have been suggested as having a role in uptake of water at during drought stress, and heavy metals contaminated soil Courtecuisse, (1999). The hyphae of arbuscular mycorrhizal fungi penetrate roots and grow extensively between and within living cortical cells, forming a very large and dynamic interface between symbionts. The hyphae also extend from root surfaces into the surrounding soil, binding particles and increasing micro- and macroaggregation Auge, (2001). The VAM selected for the research was Glomus fasciculatum.

\section{MATERIAL AND METHODS:}

Investigation was conducted at the Department of Botany, Arts, Commerce and Science College, Narayangaon, Pune to study the response of Perennial Soybean to VA mycorrhizal inoculation.

Mature healthy seeds of Perennial Soybean were collected from Khanadala (Khambatki) Dist- Satara, Maharashatra. Earthen pots with $30 \mathrm{~cm}$ diameter, and depth, with a hole at the base for drainage system were selected and were filled with $3 \mathrm{~kg}$ of sterilized soil mixture of 
sand: soil: FYM in 1: 2: 1 proportion. The pots were placed in full sunlight and were watered till field capacity a day before sowing and alternate days till the final harvest. Recommended phosphate fertilizer was procured from Suryakant agro service, Kalamb added at different levels as suggested in various treatments.

In Perennial Soybean. there were five sets with five treatments in sterilized soil.

Set I - UP00

Control, uninoculated without phosphate.

Set II - IPOO - VAM inoculated without phosphate.

Set IV - IP100\% - VAM inoculated with $1 \mathrm{gm}$ phosphate per pot.

Set III - UP75\% - Uninoculated with 0.75gm phosphate per pot.

Set IV - IP50\% - VAM inoculated with $0.5 \mathrm{gm}$ phosphate per pot.

The similar sets were made for non-sterilized soil also.

Ten root segments of each plant were collected and subjected for detection of mycorrhizal colonization. Identification is attempted by manual by Schenck and Perez, (1987). Frequency was calculated using the formula,

$\%$ frequency of mycorrhizal colonization =

$\frac{\text { Number of mycorrhizal root segments }}{\text { Total number of root segments screened }} \times 100$

\section{RESULTS AND DISCUSSION:}

UPOO (Control, un-inoculated, without phosphate \& VAM). IPOO (VAM Inoculated, without phosphate). UP100 (VAM uninoculated with $1 \mathrm{gm}$ phosphate per pot). IP100 (VAM Inoculated with 1gm phosphate per pot). IP75 (VAM Inoculated with 0.75gm phosphate per pot). IP50 (VAM Inoculated with 0.50gm phosphate per pot). Standard *deviation (SD).
The result of present investigation clearly indicates that Perennial Soybean responds well to the mycorrhizal inoculation.

Maximum plant height was observed in plants inoculated with VAM at 100 percent recommended phosphate and least in control in sterilized as well as non-sterilized soil. Past research showed that VAM alone or with phosphate increased growth of plants. (Mosse, et al., 1969) observed that mycorrhizal seedlings grow better in both sterilized and nonsterilized soil as compared to untreated plants of Onion. (Arafat et al., 1995) observed increased growth in Vicia faba in hydroponic culture.

Maximum number of leaves per branch was recorded in plants with VAM inoculum at 100 percent recommended phosphate and in control in both sterilized and non-sterilized soil it was minimum. Combinations of VAM and phosphate showed promising results. Similar trend was observed in Red Maple (Acer rubrum) reported by Daft and Hacskaylo (1977) in Tamarindus indica, L., Acacia nilotica and Calliandra calothyrus by Reena and Bagyaraj (1990).

Inoculation of plants with VAM without phosphate shows two-fold increase in vegetative growth parameters as compared to uninoculated plants without phosphate. In VAM with 50 percent recommended phosphate there was tenfold increase as compared to uninoculated plants without phosphate. Biermann and linderman (1983) reported that total leaf area was increased in inoculated plants as compared to uninoculated plants in China aster. Similar results were recorded by Kanade and Bhosale (2014) in Cassia tora L., Kanade and Bhosale (2013) in Dolichos lab-lab, Linn. and Kanade and Bhosale (2013) in Sida acuta, Burm. 
Percentage of VAM colonization was higher in mycorrhizal plants with 50 percent recommended phosphate in sterilized and nonsterilized soil as reported by (Okon et al., 1996) in Gliricidia sepum and Senna siamea. There is increase in VAM colonization level in nonsterilized soil inoculated with VAM similarly reported by Bagyraj and Manjunath (1980) in Cotton Cowpea, Menge, et al., (1998) in Citrus. Present investigation clearly indicates that Perennial Soybean (Neonotonia wightii (Wight \& Arn.) J.A. Lackey) responded positively to Glomus fasciculatum. VAM inoculation in combination with Phosphate at all levels increased height of plants and number of leaves per branch.

\section{CONCLUSION:}

Neonotonia wightii (Wight \& Arn.) J.A. Lackey is competitive growing cover weed which requires no special care to be taken and grows intensively in natural habitat. It can be cultivated to compete with unwanted under cover weeds Considering its nitrogen fixing ability and fodder value Perennial Soybean must be brought in main stream of cultivation as fodder cover crop. However, VAM inoculation will help increase its productivity and commercial status.

\section{REFERENCES:}

Adlakha, P. A., A. K. Shrivastava, S. S. Shirohi, \& V. K. Sharma, 1971. Weed Flora of Ludhiana, India. J. Weed Sci. 3: 37-44.

Arafat, S. M., Sherif, M.A., Enany, M. H. and Saad, R. N. (1995). Effect of Rhizobium and VAM on growth, phosphorous and nitrogen uptake by Vinca fabia L. in hydrophonic culture. Egyptian Journal of Soil Science. 35 (1): 117-128.
Auge RM (2001) Water relation, drought and VA mycorrhizal symbiosis. Mycorrhiza, 11: 342.

Bagyaraj, D. J. and Manjunath, A., (1980). Response of crop plants to VAM (G. fasciculatai inoculation in an unsterile indian soil. New Phytol.85 (1): 33-36.

Biermann, B. J. and Linderman, R. G. (1983). Effect of container plant growth medium and fertilizer P on establishment and host growth response to VAM fungus J. Am. Soc. For Hort. Sci 108: 962-971.

Courtecuisse R (1999). Mushrooms of Britain and Europe, Collins and the Wildlife Trusts.

Cox, G., Tinker, P. B. and Wild, J. A. (1975). Ultra-Structural evidences relating to host endophyte transfer in a Vesicular arbuscular mycorrhiza. In: Endomycorrhizas (Eds), Sanders, F. E., Mosse, B. and Tinker, P. B. Academic Press. London. 297-312.

Daft, M. J. and Hacskaylo,E. (1977). Growth of endomycorrhizal and non mycorrhizalred maple seedling in sand and anthracite soil. For. Sci. 23(2): 207-216.

Kanade AM and Bhosale RS (2013) Influence of VAM (Glomus fasiculatum) and Rhizobium on Vegetative and reproductive Parameters of Dolichos lab-lab, Linn. Ad. Plant. Sci vol 26 (II): 561-566.

Kanade AM and Bhosale RS (2013) Influence of VAM (Glomus fasiculatum) and Rhizobium on Vegetative and reproductive Parameters of Sida acuta, Burm. International Journal of Multidisciplinary Research Vol. 7(2): 2729.

Kanade AM and Bhosale RS (2014) Influence of VAM (Glomus fasciculum) on Vegetative and Reproductive Parameters of Cassia tora Linn. Int. J. of Life Sciences, 2014, Vol. 2(4): 363-365 
Lin, X. G., Hao, W. G. and Wu, T. H. (1993). The beneficial effect of dual inoculation of VAM plus Rhizobium on growth of white clover. Trcnicultura-11 (4): 151-154.

Menge, J. A., Labanuuskus, C. K., Johmson, E. L. V. and Platt, R. G. (1998). Partial substitution of Mycorrhizal fungi for Phosphorous fertilization in the green house culture of Citrus. J. Soil Sci. Soc. Am. 42: 926-930.

Mosse, B. (1973). Plant growth responses to vesicular arbuscular mycorrhizae. IV.In soil given additional phosphate. New Phytol. 72: 127-136.

Mosse, B. and Hepper, C. M. (1975). Vesicular arbuscular mycorrhizal infection in root organ cultures. Physiol. plant Pathol.5 : 215223.
Mosse, B., Hayman, D. S. and Ide, G. J. (1969). Growth response of plants in unsterilized soil to inoculation with vesicular arbescular mycorrhiza. Nature. 224 : 1031-1032.

Okon, I. E., Osunobi, O. and Sanginga, N. (1996). VAM effects on Glericidia sepum and Senna siamea in a fallowed alley cropping system. Agroforestry systems. 33 (2): 165175

Reena, J. and Bagyara, D. J. (1990). Growth stimulation of Tamarindus indica by selected VA mycorrhiza fungi. World $J$. Microbiol. Biotechnol. 6 (1): 59-63.

Schenck, N. C. and Perez, Y. (1987). Manual for Identification of VA mycorrhizal fungi, University of Florida, Graineville, Florida.

Table 1: Growth performance of Perennial Soybean in response to various levels of phosphate, and VAM in non-sterilized and sterilized soil.

\begin{tabular}{|l|c|c|c|c|c|c|}
\hline Soil type & \multicolumn{7}{|c|}{ Non sterilized } \\
\hline Set & I & II & III & IV & V & VI \\
\hline Treatments & UP00 & IP00 & UP100 & IP100 & IP75 & IP50 \\
\hline Parameters & $*$ & & $*$ & & $*$ & $*$ \\
\hline Plant height (m) & $7.2 \pm 0.1$ & $10.30 \pm 0.1$ & $12.1 \pm 0.2$ & $16.01 \pm 0.2$ & $15.00 \pm 0.2$ & $15.00 \pm 0.01$ \\
\hline $\begin{array}{l}\text { Avg. No. of } \\
\text { Leaves/branch }\end{array}$ & $\begin{array}{c}10.00 \pm \\
00\end{array}$ & $14.00 \pm 00$ & $12.66 \pm 0.1$ & $18.00 \pm 0.11$ & $15.00 \pm 0.1$ & $13.03 \pm 0.1$ \\
\hline $\begin{array}{l}\text { \% VAM Colonization } \\
\text { O0 }\end{array}$ & 11.1 & 00 & 40.2 & 20.6 & 10.5 \\
\hline $\begin{array}{l}\text { Spore count (Per 50 } \\
\text { gm of soil) }\end{array}$ & 00 & 09 & 00 & 27 & 28 & 24 \\
\hline
\end{tabular}

\begin{tabular}{|c|c|c|c|c|c|c|}
\hline Soil type & \multicolumn{6}{|c|}{ Sterilized } \\
\hline Set & I & II & III & IV & V & VI \\
\hline Treatments & UP00 & IPO0 & UP100 & IP100 & IP75 & IP50 \\
\hline Parameters & * & * & * & * & * & * \\
\hline Plant height (m) & $7.02 \pm 0.2$ & $13.20 \pm 0.01$ & $14.01 \pm 0.2$ & $19.05 \pm 0.1$ & $19.01 \pm 0.1$ & $17.00 \pm 0.2$ \\
\hline $\begin{array}{lcc}\text { Avg. } & \text { No. } & \text { of } \\
\text { Leaves /branch } & \end{array}$ & $\begin{array}{c}16.00 \pm \\
00\end{array}$ & $13.00 \pm 0.1$ & $18.66 \pm 0.1$ & $20.10 \pm 0.2$ & $20.00 \pm 0.3$ & $19.01 \pm 0.3$ \\
\hline \% VAM Colonization & 00 & 11 & 00 & 51 & 17 & 20 \\
\hline $\begin{array}{l}\text { Spore count (Per } 50 \\
\text { gm of soil) }\end{array}$ & 00 & 12 & 00 & 29 & 25 & 26 \\
\hline
\end{tabular}

